\title{
Mapping Postmodern in Toni Morrison's Beloved
}

\author{
Chuen-Shin Tai
}

\begin{abstract}
Beloved is Morrison's fifth neo-slave narrative novel and indeed a triumph. The epigraph of Beloved is from the Bible, Roman 9:25 "I will call them my people, which were not my people; and her beloved, which were not beloved." Within this epigraph, Morrison claims an identity for black people that entails both pain and cure. Thus, this passage is a statement of hope for the future of black people in trying to establish their identity. Morrison calls upon the black people to form a new black body that traces the origins of their black culture and ancestors. In this novel, Morrison struggles to keep the memory of the black people alive lest it be not forgotten in their hearts. That is to say, within the work of fiction, only when characters can face the brutal past do they begin to see and live out the bright future ahead. Nonetheless, Morrison's Beloved is truly a story to be passed on to begin for the route of healing.
\end{abstract}

Index Terms-Community, individuality, identity, postmodern, rememory.

\section{INTRODUCTION}

This report seeks to present Beloved as a postmodern novel. The paper analyzes Morrison's achievement in subverting and challenging the literary conventions of the Euro-American tradition. My undertaking in this report is to apply the concepts of the postmodern to the novel, Beloved. In so doing, I distinguish the postmodern in terms of: 1 . the narrative strategies 2. the diverse experience of African culture 3. a critique of representation 4. an awareness of intertextuality 5 . open ended interpretations. Thus, in this report, I would like to illustrate how Beloved shares in postmodern features. In addition, I will present how Morrison circumvents the limitations and boundaries of the postmodern and modern. That is to say, Morrison rejects modernism's alienation of the self and postmodernism's fragmentation of the subject. In other words, Morrison affirms the connection of the individual self and other while the true self can still preserve itself. I would like to investigate Morrison's new experiments with the postmodern methods. Therein Beloved explores a new area beyond the traditional conventions and a more focused insight into the nature of blacks. In the first part of the paper, I give a brief history and summary of the postmodern then in the second part present a textual analysis of the postmodern in Beloved.

\section{POSTMODERN THEORY}

The postmodernist period can be dated from 1967 and 1968. One aspect is the anti-scientific mentality that occurred

This work was supported in part by Shih Chien University. Chuen-shin Tai is with the Applied English Department.

Chuen-Shin Tai is with University Kaohsiung Campus, Kaohsiung City, Taiwan (e-mail: kellytai@g2.usc.edu.tw). in 1967 and the other is the alternative politics of 1968 . Structuralism lost its appeal and favor due to its scientific theory of causation causes and the vision of society as a predetermined force field. Different from structuralism, postmodernism drops the objectivist and impersonal discourse and takes on the issues of creative writing. The three terms, postmodern, postmodernity and postmodernism are often used interchangeably. However, for many, postmodern and postmodernity implies the common general development of the period and postmodernism infers the cultural mode.

Ihab Hassan traced postmodernism to Frederico de Onis who first used the term, postmodernismo. On the other hand, Charles Jencks states that it was originally used by a British artist named John Watkins Chapman in the 1870s and in 1917 by Rudolf Pannwitz. However, the term postmodern became to have a greater significant in the $1960 \mathrm{~s}$. In the beginning, postmodernism referred to the new period of culture after the Second World War. Jean-Francois Lyotard's The Postmodern Condition: A Report on Knowledge (Manchester University Press, 1979) is said to have begun it. Another contributor is French writer Jean Baudrillard with Simulations (1981, translated 1983). Baudrillard claims the loss of the real due to the contemporary presence and the existence of the mass media.

Postmodernism is a frequent term used to describe literature from the 1960s to the present day. It is a clear concept that includes a broad wide range of areas, including art, architecture, music, film, literature, sociology, communication, fashion and technology. In fact, postmodernism breaks with modernist conventions and questions knowledge in the traditional sense. More specifically, the term is used in number of ways: 1 . to refer to non-realist and non-traditional literary work of the post-Second World War period; 2. to take modernism to the extreme; 3 . to symbolize a larger human condition in the late capitalist world. [1]

The movement of the modernist period held sway during 1910 to 1930 and the first founders were famous figures such as Virginia Woolf, James Joyce, T. S. Eliot, Ezra Pound, Wallace Stevens, Franz Kafka and Rainer Maria Rilke. These writers experimented with new forms, structures, styles and replaced traditional coherence with fragmented utterances. The modern era is strongly connected and linked with the European Enlightenment. The basic element of Enlightenment is the central ideas of humanism. For many modernist, mankind is doomed to exist and live in the modern society. This idea later led to the gradual development of internal monologue, stream-of-consciousness and dramatic monologue. Alienation is also an important factor in modernism. Hence, communication between human beings is often consider to be difficult and can be even impossible at certain times. 
Postmodernism is related to modernism in the sense of continuing to challenge, alter and even subvert the conventional habits of one's thought. Postmodernism is used in a boarder and wider range than modernism, referring to a larger group of the society and the general human condition. In ways, modernism and postmodernism share similar grounds in their common ideas of rejecting and questioning the boundaries between low and high art, rejection of genre distinctions, emphasizing parody, irony and playfulness. Barry states modernism tends to lament its fragmented view of human subjectivity while postmodernism celebrates it. [2] Ihab Hassan, contrasts the modernist 'dehumanization of Art' with the postmodernist sense of 'dehumanization of the Planet, and the End of Man'. Postmodernism takes the subjective idealism of modernism to the point of solipsism, but rejects the dark pessimistic in modernism. In many other accounts the postmodernism is more welcoming as it celebrates the new attitude of the modern world. Modernism respond to high technology and the dominance of the commercial with horror and fear while postmodernism reacts with a more accepting open manner. By contrast, postmodernism rejects the distinction between high and popular art, which in modernism is crucial.

The postmodern marked the end of Western supremacy and the decline of individualism and capitalism. In fact, the postmodern is the mixture of the literary genres. In this regard the idea is the disappearance of the self. Also, a concern of the postmodern is the intertextual elements in literature. For example, the term intertextuality is used to signify the multiple and various ways in which a literary text is inseparable from other texts. Accordingly, all texts are in fact undoubted linked with other texts. Including those that will be written in the future to come. That is to say, the postmodern foregrounds irony in the text. While the modernist tries to destroy and deconstruct the past, the postmodernist understands that the past must be revisited but with the feature of irony.

Nonetheless, the postmodern signals a loss of old tradition and values, a release and rejection from high culture and the welcoming of the new forms of modern arts and media. The postmodern rejects elitism, the sophisticated formal experimentation and the tragic sense of the self-found that is often found in many modernist writers. The postmodern also reflects ontological uncertainty. That is to say, neither the world nor the self possesses unity, meaning and coherence anymore. Woods states the idea de-centering of the subject. [3] In general, postmodern blurs and breaks down the conventional lines between fiction and history. Postmodernism in literature undertakes the task and work of subverting the order of language. Moreover, they reveal the existence of meaningless and nothingness. This is also known as the loss of the real. For many, postmodern theory signals a distance within the critic from representation. In a word, postmodern repeatedly is the central concept of exhaustion and the open ending of texts.

\section{MORRISON'S BELOVED}

Following is an example of postmodern criticism with a straightforward application of its ideas to Morrison's Beloved. The first phase of analysis is the features of narrative strategies in the postmodern. Morrison peruses postmodern devices in the use of narrative fragmentation, multiplication of voices and participatory reading. By doing so, Morrison displays one of the most important features, which is the multiple narrative: "This approach articulated a new mode of postmodern self organised around concepts of plural and multiple identities and decentered or displaced consciousnesses." [3] One of the examples in the novel appears when the three central female characters, Sethe, Denver and Beloved, talk and speak to each other by using one voice. In such manner, they express their inner-most feelings. In this chapter, the three women intertwine their memories, voices and minds. Eventually, the three women become as one. The passage joins their three voices as Beloved becomes Sethe, Beloved is Denver, Sethe is Beloved, Sethe is Denver, Denver is Sethe and Denver is Beloved: "The blurring of distinction between self and others, which in Beloved takes the form of Sethe's inability to see herself as separate from her children, a blurring which reinforces the concept of the subject as both constituted and constituting." [4] Their identities blur into one as the voices of Sethe, Denver and Beloved merge together. The three voices integrate as a unit.

Significantly, the three voices stand for the living, dead, and unborn black people: "Telling the stories of women across generations, their fiction not only offers us roots to know our history but wings to pass it on." [5] That is to say, the blended voices present the past, present and future. Another aspect centers on fluidity of meaning, which is a feature of the postmodern. As we read through the novel, the narration becomes more complex and ambiguous. For instance, Beloved's monologue becomes undecipherable. The sentences contain no punctuation. This significant feature allows a fusion of black voices, minds and identities. In this way, Morrison depicts Beloved with plural identities and faces.

In several other passages, each character controls his/her own narration. For example, in one part Sethe tells Paul D why she killed her daughter during the attempted escape. In another section, Paul D is narrating his dreadful escape from the plant house and his lonely days of drifting outside. In other parts, Beloved presents her monologue as she remembers her terrifying experience during the passage on the slave ship being piled up quickly with many other dead and living bodies. Also, Denver speaks of her horrible childhood memories and miserable school life for years Baby Suggs talks about the clearing in the back yard:

Together they stood in the doorway. For Sethe it was as though the clearing had come to her with all its heart and simmering leaves, where the voices of women searched for the right combination, the key, the code, the sound that broke the back of words [6].

The clearing is calming rather than presented in a dark mood. In fact, these characters only talk about fragments of their past. The fragmentary discontinuous and narrations reveal elements of the postmodern. Indeed, all the protagonists participate by telling his or her side of the story. What also comes back to life through the stories of each character in Beloved is their black history: "No matter how vile or horrendous the act of an individual member, the community must remain intact." [7] Every story implies a 
personal experience but in broken pieces or parts. Perez describes: "In order for Sethe to move forward she must reencounter Beloved, both as her daughter and an as emblem of the past." [8] This implies that the characters need to confront their pain piecemeal, seek renewal together and return to the community once again. Only by telling their stories can blacks discover a literature of their own through the recovery of black ancestors.

Next, Morrison subverts the traditional convention of omniscient narration through the use of the pronoun "you." Morrison allows the readers to be a part and portion of the black story. The readers join and connect the story relating it with the narrators. Thus, the readers participate in the production of the text. As Morrison affirms in her interviews, her writing is about involving and reaching the readers. A characteristic of the postmodern is to put stress on the reading rather than the text itself. Each reader extends himself/herself in the story and becomes a narrator in the story-telling process. Once again, the employment of "you" is the link between the text and reader. In other words, readers must make connections with the characters and voices to understand their mind. Beloved highlights the idea that the readers can play an active role. The reader then, in postmodern terms, may acknowledge and see his or her presence and the power of manipulation. The result is that the reader is not just a passive receiver but a joint member producer in retelling his/her history. Clearly, the point is that there is no possible true revelation. This suggests the reader must be active in understanding his or her own position of participation in discourse.

The second feature of the postmodern is the diverse African-American culture in Beloved. Rather than presenting a linear plotting and single center of the classic style, Morrison declaims the past as a whole fixed reality: "There is nothing in Beloved that denies the past, nor negates a future, although for Sethe the future had been a matter of keeping the past at bay." [4] Morrison presents the transformation of the African tradition and the importance to experience self-actualization. In fact, this text examines the black culture and people. By rewriting the old slave narrative, Morrison offers a hybrid genre of a neo-slave narrative that features different stories: "All of it is now it is always now there will never be a time when I am not crouching and watching others who are crouching too I am always crouching the man on my face is dead his face is not mine." [6] In the postmodern perceptive, pluralism is a very salient concept. Instead of shaping the old ideological orientation of slavery, Morrison reexamines the diversity of African American culture. More specifically, Morrison reminds the black people of their heritage and past ancestors, because what is repressed will eventually resurface again as surely as a memory that has been ignored or overlooked: "The past, until you confront it, until you live through it, keeps coming back in other forms. The shapes redesign themselves in other constellations, until you get a chance to play it over again." [9] This feature seeks to learn about the black and white cultural matrix. Constantly, Morrison notes on the absence of blackness in the presence of American literary discourse.

The third postmodern underlying mark is the narrative structure of magic realism. The novel is a critique of representation in that it fuses both the magic and real.
Lobodziec explains: "Magic seems to stand for the extraordinary capacity of enslaved African Americans to transcend the oppressive reality." [10] Thus, Beloved is a text of a fantasy world. This blurring is depicted in the spiritual and the material world, the living and dead, and the past, present and future. Also, Beloved's identity is a puzzle to others within the novel. Could Beloved possibly be Sethe's baby girl that was murdered? But how could this be true since the baby died many years ago: "Was it true the dead daughter come back? Or a pretend?" [6] Perhaps Beloved is a ghost-like child to haunt Sethe in her own home. As critics have stated, magic realism is employed as a substitution. Magic realism relates to Beloved most of all because she is the dead daughter of Sethe. Within the text, magic realism highlights and describes a world that cannot be a signified or signifier.

The postmodern asserts the notion of intertextuality. In other words, the text echoes the connection of countless outside texts within Beloved. This idea includes the form of counter memory in the blending of the past, present, and future refereed as rememory. For instance, rememory traces the threads beyond to the outside world. Rememory is a link in a network that weaves together the memories of many people. Moreover, rememory functions as a form of connection with black ancestors, too. Obviously, rememory expresses a strong connection with the past. An instance of intertextuality is the true story of Margaret Garner a slave that escaped from her owner, a historical figure. By using this event, Morrison reshapes the past history and rewrites a new page of American history as a narrative of defiance against other versions of slavery: "Morrison clearly sought to base Beloved on a wider range of texts than the traditional slave narrative - texts that challenge and revision authoritative versions of slavery." [11] This peculiarity of history makes a different statement about the historical novel. Morrison's slavery novel is manifestly an example of the use of intertextuality with many other stories about collective history. Evidence stems from the epigraph, which is dedicated to the sixty million black people who died during the passage trip to the new land and home of America. Beloved is not just a girl but symbolizes the black people: "Beloved represents not only the spirit of Sethe's daughter; she is also the projection of repressed collective memory of a violated people." [7] Within the epigraph, each voice and story of a dead spirit tells of his or her sad story: "Morrison's characters stand in for all those slaves and former slaves who were unceremoniously buried without tribute or recognition." [12] Beloved represents the black heritage and ancestors. Also, she is the lost past that helps black people to face the brutal injustice. Thus, Beloved conjoins with many other suffering texts of the black people.

The last element is the varied interpretations of the text and the open-ended statements. This signifies interpretations with many expanded and unfolded meanings. Within the novel of Beloved, a famous line tells that the story is not to be passed on: "Postmodernism resists closure in that it insists that we try to constantly keep our own subject positions, history, and motives in mind as we interpret, that we recognize how each interpretation is also a domination, a will of power." [5] This sentence contains wide meanings. One meaning could be that the story and suffering should come to a stop and not be 
passed on to the next generation. This idea discloses how the traumas and mistakes must not occur again. People should be able to learn from the past: "If survival does depend on forgetting, then they're all doomed, because the past keeps leaking through." [9] However, another meaning is that the story should not be ignored and forgotten: "It's when you bump into a rememory that belongs to somebody else. Where I was before I came here, that place is real. It's never going away." [6] This implies how the present is constructed by the past. Thus, the past belongs to the future.

Besides, another example of an open answer is the identity of Beloved. Nobody knows where she comes from or her family background: "Everybody knew what she was called, but nobody anywhere knew her name." [6] Who is Beloved? This is a question with more than just one answer. For Beloved can be the ghost of the unknown blacks that died during the middle passage, the ghost of Sethe's baby daughter, or a girl who just simply got lost like Paul D suggests. In addition, her disappearance provides many various interpretations. Some say she vanished like a ghost and others say she just ran away. Though Beloved is gone at the end, she spiritually lives out her name. Hence, Morrison warns that knowing and keeping the black family name is decisive for blacks who in slavery were nameless. Truly, a name is to be respected and treasured. Nonetheless, the black community is enhanced and uplifted to a greater understanding of who they are.

Clearly, the postmodern is about language. Different from other theories, the postmodern is about how we control and determine language. Likewise, in Beloved, the word according to postmodernism, as used, refer to race, class, gender, identities, age, nationality and ethnicity. It's all about difference. It's also about power and the powerless: "It not only teaches us to value our ancestors of nommo- the power of the word- to help us name ourselves and shape our lives in the tradition of our ancestors." [5] There is no conclusion in the postmodern. A major concern of the postmodern is histories not told, retold, hidden, forgotten, invisible, unimportant and changed. It's about the refusal to read history as linear and in the conventional sense. Thus, Beloved offers a new modal of history. Beloved goes beyond the superficial of conventional history and serves to resurrect the ancestors spirit that has long been buried. In these terms, Beloved remarkably tells the history of the unknown and presents a rich testimony of black ancestry.

\section{CONCULSION}

In all, I have discussed the postmodern devices in the novel Beloved. The paper has offered a brief but definitive textual analysis and theoretical application of postmodern practices. With its characteristics and traits of postmodern, Beloved is an innovative piece of great work. In addition, Morrison's usage of the postmodern features is extensive in that it challenges the limits of modernism and postmodernism.
While modernism emphasizes the alienation of the self and postmodernism stresses the fragmentation of the individual, the ending of Beloved is the harmony of the self with a black name and community: "The symbolic geography in Beloved is most certainly not the North, but the land on which, at any given time and place, blacks immerse themselves in a loving consortium called community." [7] In other words, Beloved accepts the alienation of self and fragmentation of the other. As Lillvis states: "The repetition of "me," significantly stated two times, can be understood to reference Sethe's liminal or multiple identity: she is both daughter and mother, self and other." [13] By reclaiming the links with the black community, the characters regain their original sense of heritage. Without their black ancestors and community, blacks are lost. Rather than the isolation and individuation of the self, however, Beloved is the merging of a complete self in a community.

\section{REFERENCES}

[1] J. Hawthorn, A Glossary of Contemporary Literary Theory, New York: Oxford UP, 2000.

[2] P. Barry, Beginning Theory, New York: Manchester, 1995.

[3] T. Woods, Beginning Postmodernism, New York: Manchester, 1999.

[4] B. Marshall. Teaching the Postmodern: Fiction and Theory, New York: Routledge, 1992.

[5] M. Mobley, Folk Roots and Mythic Wings in Sarah Orne Jewett and Toni Morrison, Baton Rouge: Louisiana State University, 1991.

[6] T. Morrison, Beloved. New York: Penguin, 1987.

[7] D. Heinze, The Dilemma of Double-Consciousness, London: University of Georgia Press, 1993.

[8] R. Perez, "The debt of memory: Reparations, imagination, and history in Toni morrison's beloved," Women's Studies Quarterly, vol. 42, no. 1/2, pp. 192-200, 2014.

[9] R. David, Toni Morrison Explained, New York: Random House, 2000.

[10] A, Lobodziec, "Toni morrison's discredited magic - Magical realism in beloved revisited," Brno Studies In English, vol. 38, no. 1, pp. 103-121, 2012.

[11] L. Peach, Toni Morrison, New York: Macmillan Press, 2000.

[12] J. Furman, Toni Morrison's Fiction, South Carolina: University of South Carolina, 1996.

[13] K. Lillvis, "Becoming self and mother: Posthuman liminality in Toni morrison's beloved," Critique, vol. 54, no. 4, pp. 452-464, 2013.

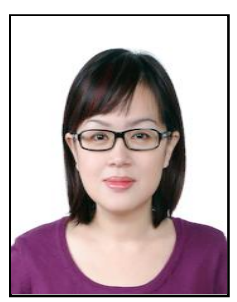

Chuen-shin Tai was born in Taipei, Taiwan. Chuen -shin earned the following degrees; bachelor of arts in English literature from National Sun Yat-sen University, Taiwan, in 1999; She received her master of arts in English literature from National Kaohsiung Normal University, Taiwan in 2002; She received her Ph.D. of arts in English literature at National Kaohsiung Normal University in 2008. She major field of study are Asian-American literature. She is now a teaches at Shih Chien University Kaohsiung Campus in Taiwan. Her publications include: "The voice of silence in joy kogawa's obasan," Chaoyang Journal of Humanities and Social Science, vol. 10, no. 2, pp. 203-222, 2012; "Love, loss and forgiveness in amy tan's the joy luck club," in Proc. 6th Global Conference: Forgiveness. Oxford: Inter-Disciplinary.net, July 2013; "Healing gardens: Creating a living space in shani mooto in a garden of her own," International Journal of Arts \& Sciences' (IJAS) International Conference for Social Sciences and Humanities, Prague July 2015; "The blue envelope from London in V.S. naipaul's half a life," Institute of English Studies, University of London July 2015; "Metamorphosing jasmine: Identity sorting in bharati mukherjee's jasmine," IJSSH, January 2016. At present, she is working on mapping identities for minority writers. 